\title{
Moroccan Formulation of Oils for the Care of Hair: Chemical Composition and Antibacterial Activity
}

\author{
Tarik Ainane ${ }^{1 *}$, Said Gharby ${ }^{2}$, Mohammed Talbi ${ }^{3}$, Abdelmjid Abourriche ${ }^{4}$, Ahmed Bennamara ${ }^{4}$, \\ Naoual Oukkache ${ }^{5}$, Hassan Lamdini ${ }^{6}$ and Mohamed Elkouali ${ }^{3}$ \\ ${ }^{1}$ Superior School of Technology - Khenifra (EST-Khenifra), University of Moulay Ismail, PB 170, 54000 Khenifra, Morocco \\ ${ }^{2}$ Laboratory of Chemistry of Plants, Organic Synthesis and Bioorganic, Faculty of Science, University Mohammed V-Agdal, \\ Rabat, Morocco \\ ${ }^{3}$ Laboratory of Analytical Chemistry and Physical Chemistry of Materials, Faculty of Sciences Ben Msik, University Hassan \\ II, BP 7955 Casablanca 20660, Morocco \\ ${ }^{4}$ Biomolecules and organic synthesis laboratory, Faculty of Sciences Ben Msik, University Hassan II, BP 7955 Casablanca \\ 20660, Morocco \\ ${ }^{5}$ Laboratory of Venoms and Toxins, Pasteur Institute of Morocco, 1 Place Louis Pasteur, Casablanca 20360, Morocco \\ ${ }^{6}$ Department of Infectious Diseases, IbnRochd Hospital University Center, Casablanca 20270Morocco
}

Received: 27 February, 2016; Accepted: 29 April, 2016; Published: 05 May, 2016

*Corresponding author: Tarik Ainane, Superior School of Technology - Khenifra (EST-Khenifra), University of Moulay Ismail, PB 170, 54000 Khenifra, Morocco, E-mail: ainane@gmail.com

\begin{abstract}
The objective of this work is studying the chemical composition and the antibacterial activity of a formulation used in the Moroccan tradition for hair care composed of two vegetable oils (argan oil and olive oil) and three essential oils (Thymus vulgaris, Nigella sativa, and Allium sativum). At first, we analyzed the physicochemical parameters for both vegetable oils, such as: acidity, peroxide index, saponification index, iodine index, absorption coefficients in UV at $232 \mathrm{~nm}$ and $270 \mathrm{~nm}$, and humidity, we also determined their fatty acids compositions, sterols compositions and tocopherols contents. On the other hand, the essential oils components were identified by GC/MS, the results of these analyzes showed that the major constituents of the essential oils of Thymus vulgaris and Nigella sativa were monoterpene hydrocarbons and phenolic monoterpenes, and the major constituents of the essential oil of Allium sativum were diallyl sulfides and methyl allyl sulfides. Finally, the antibacterial activity of the vegetable oils, essential oils and formulation were determined against strains bacteria, using a well diffusion agar method, where the results of this antibacterial test indicated the effectiveness of the formulation prepared during this study for cosmetics and pharmaceutical preparations.
\end{abstract}

Keywords: Formulation; Vegetable oils; Essential oils; Chemical compositions; Antibacterial activities

\section{Introduction}

Since antiquity, the use of natural products presents considerable interest for humans, but nowadays with the industrial spirit, scientific advance is being used in the development of innovative natural products in medicine, pharmaceutics, and cosmetics industries with thorough and targeted studies [1-5]. Several public and private sectors, industries and laboratories focus their research towards the development of natural products (Bio-products) because it is provide interesting turnover and millions of dollars in revenue [6-7]. Also, most consumers are choosing natural products to avoid any danger source of synthetic chemicals products that could be harmful to their health. Besides, taking into account the growing environmental issues, bio-products help to protect the environment by the ease of degradation [8-9].

On the other hand, the industrial development of natural resources in Morocco was begun for ten years, while several special industries were installed to produce Bio-products and exploit these resources [10], because Morocco is undoubtedly both a well-known name and a significant producer in the world of oils (essential oils and vegetal oils). This is the result of several main factors: The geography and climate, which is governed by the Mediterranean Sea, the Atlantic Ocean, the desert in the south and its three main mountain ranges. Morocco hosts a complete range of Mediterranean climates and soils that favour an extremely rich biodiversity, including an impressive variety of aromatic plants (both Mediterranean classics and endemic species) $[8,11]$.

Consequently, many species of plants produce seeds containing fats which are used as a food reserve for the developing seedling and they are quite often present in sufficient quantities to make their extraction, in the form of oil, worthwhile. Vegetable oils are produced from nuts, seeds, grains and beans. They are sometimes referred as fixed oils because they are not as volatile (easily evaporated) as essential oils [12,13]. Vegetable oils particularly the argan oil and olive oil have a wide range of uses, and whilst many of these involve processes that are too technical 
for small scale ventures, there are still many ways in which we can employ them as a cosmetic or pharmaceutics products [14]. Also, the essential oils are the subject of intensive scientific research and attract attention of cosmetic and pharmaceutical industries due to their potential as active pharmacological compounds or natural preservatives. Enormous diversity of this group of natural compounds and wide spectrum of biological properties make them attractive for many industries. Regardless from sensory properties of essential oils, antimicrobial and antifungal activities are the goal of research $[15,16]$.

This work is a chemical and biological study of a natural formulation from vegetable oils (argan oil and olive oil) and essential oils (Thymus vulgaris, Nigella sativa, and Allium sativum) of Moroccan tradition for hair care. This formulation has been used for several centuries in the rural areas, the Sahara and the Atlas mountains.

\section{Materials and Methods}

\section{Vegetable oils}

Argan oil was obtained from the cooperative of GIE TARGANINE. Olive oil was acquired from a supermarket (Casablanca -Morocco).

\section{Analytical determination}

The chemical and physical parameters (acidity, peroxide index, saponification index, and iodine index, absorption coefficients in UV at 232 and $270 \mathrm{~nm}$, and humidity) were analysed, in triplicate following the analytical methods described in Regulations EC 2568/91 [17].

Fatty acid composition was determined on their corresponding methyl esters by gas chromatography on a CPWa x $52 \mathrm{CB}$ column $(30 \mathrm{~m} \times 0.25 \mathrm{~mm}$ i.d.) using He (flow rate $1 \mathrm{ml} /$ min) as a carrier gas. Oven, injector, and detector temperature were set at 170,200 , and $230^{\circ} \mathrm{C}$ respectively. Injected quantity was $1 \mu \mathrm{l}$ for each analysis.

Sterol composition was determined after trimethylsilylation of the crude sterol fraction using a Varian 3800 instrument equipped with a VF-1 ms column ( $30 \mathrm{~m} \times 0.25 \mathrm{~mm}$ i.d.) and using helium (flow rate $1.6 \mathrm{ml} / \mathrm{min}$ ) as carrier gas. Column temperature was isothermal at $270^{\circ} \mathrm{C}$; injector and detector temperature was $300^{\circ} \mathrm{C}$. Injected quantity was $1 \mu \mathrm{l}$ for each analysis [18].

On the basis of the AOCS Official method Ce 8-89, tocopherols content was determined by HPLC using Shimadzu instruments equipped with a C18-Varian column $(25 \mathrm{~cm} 94 \mathrm{~mm})$. Detection was performed using a fluorescence detector (excitation wavelength $290 \mathrm{~nm}$, detection wavelength $330 \mathrm{~nm}$ ). Eluent used was a 99:1 isooctane/ isopropanol (V/V) mixture, flow rate 1.2 $\mathrm{ml} / \mathrm{min}[19]$

\section{Essential oils}

Aerial parts of the Thymus vulgaris, seeds of Nigella sativa, and fruits of Allium sativum were purchased from the local market in Casablanca (Morocco) and identified at Department of Biology, Faculty of sciences Ben M'sik University of Hassan
II - Casablanca. Voucher specimen of the plants were dried and deposited at the herbarium of laboratory. Origins of species are displayed in (Table 1).

Dried biomasses were submitted to steam distillation in a Clevenger-type apparatus for $4 \mathrm{~h}$. The essential oils obtained were separated from water and dried over anhydrous $\mathrm{Na}_{2} \mathrm{SO}_{4}$ then stored at $4^{\circ} \mathrm{C}$ until use.

The qualitative analysis of essential oils is done by gas chromatography coupled to mass spectrometry (GC/ MS: Hewlett Packard 5971A). Determining the relative proportions of various molecules obtained by gas chromatography coupled with flame ionization (GC/FID: Hewlett Packard 5890A). Analysis by GC/MS and GC/FID are made under identical conditions. GC/ MS were performed on a DB-5 column ( $5 \%$ phenyl methyl siloxane) whose dimensions are: length: $30 \mathrm{~m}$; diameter: $250 \mu \mathrm{m}$; film thickness 0.32 microns. The applied temperature program was $40^{\circ} \mathrm{C}$ for 5 $\min , 40$ to $20^{\circ} \mathrm{C}$ at $3^{\circ} \mathrm{C} / \mathrm{min}$ then held at $200^{\circ} \mathrm{C}$ for $5 \mathrm{~min}$. The carrier gas was helium (pressure: $49.9 \mathrm{kPa}$, flows: $1 \mathrm{ml} / \mathrm{min}$ ). The source of the mass spectrometer to a temperature of $230^{\circ} \mathrm{C}$ and the mass range is scanned from 50 to $350 \mathrm{amu}$ [20].

\section{Preparation of formulation}

In a graduated flask of $100 \mathrm{ml}$, was added $1 \mathrm{ml}$ of each essential oil. Afterwards, the flask completed until gauge by the mixture of argan and olive oils (1:1), and finally stored in a refrigerator at $4^{\circ} \mathrm{C}$ before analysis or use.

\section{Antibacterial activities}

The method used is the well diffusion agar described by $\mathrm{T}$. Ainane and A. Abourriche, et al. [21]. This method can quickly observe effects of a substance by bacterial growth. Screening for antibacterial activity of the products was determined by agar well diffusion method. The oils and formulation were dissolved in DMSO (Dimethyl sulfoxide) 5\%. Ten microliter of crude extract (2 $\mathrm{mg} / \mathrm{ml}$ ) was loaded onto well (diameter $6 \mathrm{~mm}$ ). Fresh colonies of Streptococcus faecalis, Escherichia coli, Staphylococcus aureus and Pseudomonas aeruginosa on supplemented MH (Mueller Hinton) agar, were inoculated in supplemented MH broth and incubated overnight under aerobic condition. The bacterial suspensions were adjusted to McFarland standard at 0.5 and spreaded onto supplemented $\mathrm{MH}$ agar plates. The seeded plates and incubated at $37^{\circ} \mathrm{C}$ for $24 \mathrm{~h}$ under aerobic condition. The diameters of the inhibition zones were measured and the mean was recorded. Experiments were done in triplicate. Bacterial culture with $1 \%$ DMSO was used as negative control. In addition, tetracyclin and streptomycin used a positive control.

Table 1: Origins of the medicinal plants used in formulation for the care of hair.

\begin{tabular}{|l|l|l|}
\hline Plants & Region & Extracted part \\
\hline Thymus vulgaris & Oujda (Eastern Morocco) & Aerial parts \\
\hline Nigella sativa & Beni Mellal (Atlas median) & Seeds \\
\hline Allium sativum & Meknes (Atlas median) & Fruits \\
\hline
\end{tabular}




\section{Results and Discussion}

After a survey carried out on natural products used in the Moroccan tradition, particularly cosmetics, we selected a formulation for the care of hair known in the population of the Atlas, where it's composed by the vegetable oils and the essential oils. This formulation is a composition of two vegetable oils: argan oil and olive oil, also made-up of three essential oils of Thymus vulgaris, Nigella sativa and Allium sativum.

\section{Analysis of Vegetable Oils}

The first part of this work was devoted to the chemical composition of this formulation. So we started with the arganoil and olive oil. (Table 2) shows the physicochemical parameters of two oils used such as: acidity, peroxide index, saponification index, iodine index, absorption coefficients in UV at 232 and 270 $\mathrm{nm}$, and humidity. Acidity is an important factor in assessing the quality of an oil and is widely used both as a test of classification of olive and argan oils, and also a factor that informs the oil alteration by hydrolysis. The acidity of argan oil and olive oil are respectively $0.30 \%$ and $0.62 \%$. The peroxide value, saponification value and iodine value are parameters depend by the physicochemical properties and stability of fatty acids. The peroxide value of argan oil and olive oil are respectively: 1.1 meq/ $\mathrm{kg}$ and $2.1 \mathrm{meq} / \mathrm{kg}$, saponification values are respectively: $189.9 \mathrm{mgKOH} / \mathrm{g}$ and $194.5 \mathrm{mgKOH} / \mathrm{g}$, and the iodine value are respectively: 98.3 and 87.7 . Other parameters studied are the absorption coefficients in UV at 232 and $270 \mathrm{~nm}$, because the conjugated diene have a strong absorption band in the ultraviolet near $232 \mathrm{~nm}$ and the triene have a triple band at $270 \mathrm{~nm}$. Determining the absorbance in the vicinity of two wavelengths allows for the detection and evaluation of primary and secondary oxidation products. The results obtained for argan oil are: $\mathrm{K}_{232}=$ 1.19 and $\mathrm{K}_{270}=0.20$ and for olive oil are: $\mathrm{K}_{232}=1.71$ and $\mathrm{K}_{270}=0.16$. Humidity is the moisture and volatile matters is the weight loss experienced by the product after heating to $103^{\circ} \mathrm{C} \pm 2^{\circ} \mathrm{C}$ in the operating conditions, the results obtained of argan and olive oils are respectively: $0.06 \%$ and $0.04 \%$. According to the parameters recommended in the literature and the authorized values (norm) [17], both vegetables oils used are fresh and they having a good quality.

From another side, vegetable oils are essentially defined by their major composition of fatty acids and their minor composition of sterols and tocopherols. The study of the fatty acid composition of argan oil and olive show that oleic acid (46.9\% and $74.6 \%$ ) and linoleic acid (33.3 \% and $10.7 \%$ ) are the majority fatty acids followed by palmitic acid and stearic acid. The analysis of total sterol gives very interesting results, $169 \mathrm{mg} / 100 \mathrm{~g}$ for argan oil and $207 \mathrm{mg} / 100 \mathrm{~g}$ for olive oil, also tocopherols have an minor composition for both oils, where the total tocopherol for argan oil is $738 \mathrm{mg} / \mathrm{kg}$ in which a predominant amount of $\gamma$-tocopherol, and the total tocopherol for olive oil is $182 \mathrm{mg} / \mathrm{kg}$ in which a predominant amount of $\alpha$-Tocopherol. All results of analyzes of fatty acids, total sterols and tocopherols are displayed in (Table $3)$.

\section{Analysis of essential oils}

After the distillation of essential oils, the determination of yield of each oil was calculated and then the values found were: $1.12 \pm 0.21 \%$ for Thymus vulgaris, $0.83 \pm 0.03 \%$ for Nigellasativa, and $0.52 \pm 0.17 \%$ for Allium sativum. Therefore, qualitative analysis of essential oils of Thymus vulgaris, Nigella sativa, and Allium sativum made by gas chromatography coupled to mass spectrometry GC/ MS are shown respectively in (Table 4, Table 5 and Table 6).

Analysis results of essential oil of Thymus vulgaris give identification of $90.8 \%$ of these constituents. The majors compounds identified are: thymol (47.4\%) and p-cymen $(17.0 \%)$, and other compounds also detected with interesting percentages: $\beta$-caryophyllene (3.5\%), carvacrol (3.2\%), linalool $(2.4 \%), \alpha$-thujene $(2.2 \%), \quad \gamma$-terpinen $(2.1 \%), \quad$ terpinen-4-ol (1.9\%), cadinene $(1.8 \%)$, camphene $(1.8 \%), \beta$-myrcene $(1.4 \%)$, borneol (1.3\%), and $\alpha$-pinen (1.2\%).

The second analysis of essential oil of Nigella sativa shows the presence of p-cymen (60.5\%) as the major compound of the oil, also, the analysis confirms existence the other compounds with remarkable percentages such as: $\alpha$ - thujene $(6.9 \%)$, thymoquinone (3\%), carvacrol $(2.4 \%)$ and $\beta$-pinene $(2.4 \%)$, and other compounds with low yields. All of the identified compounds of this essential oil a yield of the order of $87.5 \%$.

Finally, analysis of essential oil of Allium sativum shows that all detected compounds are types of diallyl sulfide and methyl allylsulphides. The indentified total compounds present $74 \%$. The major compounds are: diallyl disulfide (18.8\%), methyl allyl trisulfide (16.3\%) and diallyl trisulfide (15.9\%), also other

Table 2: Physicochemical parameters of argan oil and olive oil used in this study.

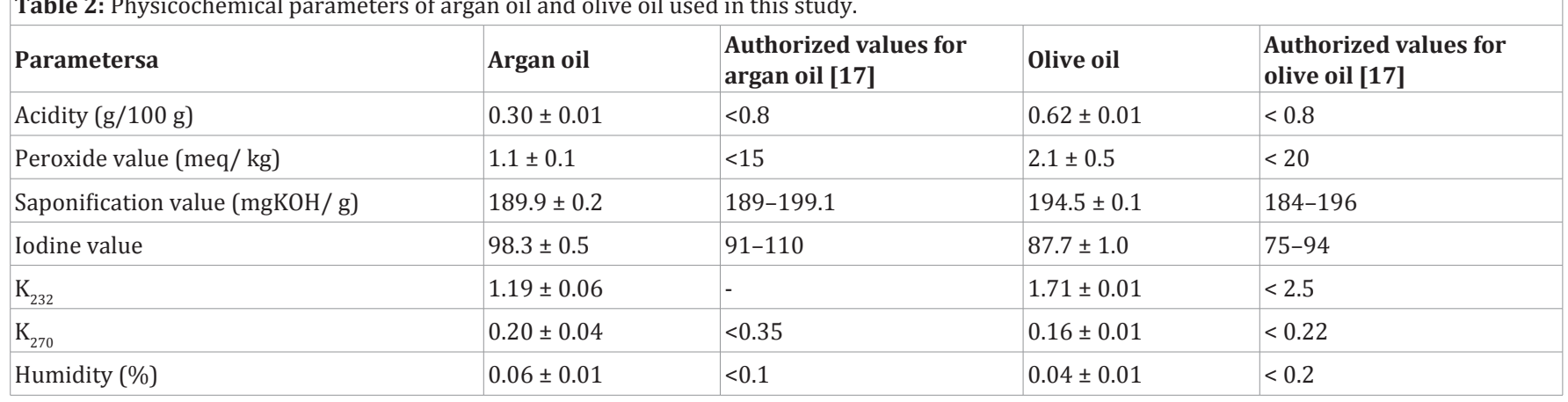


Table 3: Fatty acid, sterol, and tocopherol composition of argan oil and olive oil.

\begin{tabular}{|l|c|c|c|}
\hline & Composition & Argan oil & Olive oil \\
\hline \multirow{4}{*}{ Fatty Acids (\%) } & Palmitic acid & $12.1 \pm 1.5$ & $9.2 \pm 1.5$ \\
\cline { 2 - 4 } & Stearic acid & $6.2 \pm 1.0$ & $2.9 \pm 0.5$ \\
\cline { 2 - 4 } & Oleic acid & $46.9 \pm 1.5$ & $74.6 \pm 2.5$ \\
\cline { 2 - 4 } & Linoleic acid & $33.3 \pm 1.5$ & $10.7 \pm 1.5$ \\
\hline Sterols (\% total sterols) & Linolenic acid & $0.08 \pm 0.10$ & $0.9 \pm 0.1$ \\
\hline \multirow{3}{*}{ Tocopherols (mg/ kg) } & Total sterols (mg/ 100 g) & $169 \pm 10$ & $207 \pm 10$ \\
& $\alpha$-Tocopherol & $49.5 \pm 6.0$ & $167 \pm 15$ \\
\cline { 2 - 4 } & $\beta$-Tocopherol & $1.5 \pm 0.6$ & $10.5 \pm 2.5$ \\
\cline { 2 - 4 } & $\gamma$-Tocopherol & $651.4 \pm 2.0$ & $2.3 \pm 0.3$ \\
\hline & $\delta$-Tocopherol & $57.3 \pm 6.0$ & $20.1 \pm 6$ \\
\hline
\end{tabular}

Table 4: Percentages of chemical compositions of the essential oil Thymus vulgaris.

\begin{tabular}{|c|c|c|c|c|c|}
\hline Comp. & Structure & Percentage & Comp. & Structure & Percentage \\
\hline 1 & & $\begin{array}{l}\alpha \text {-humulene } \\
0.2 \%\end{array}$ & 11 & & $\begin{array}{l}\beta \text {-caryophyllene } \\
3.5 \%\end{array}$ \\
\hline 2 & & $\begin{array}{l}\alpha \text {-Pinen } \\
1.2 \%\end{array}$ & 12 & & $\begin{array}{l}\gamma \text {-Terpinen } \\
2.1 \%\end{array}$ \\
\hline 3 & & $\begin{array}{l}\text { Sabinen } \\
0.7 \%\end{array}$ & 13 & & $\begin{array}{l}\text { Terpinen-4-ol } \\
1.9 \%\end{array}$ \\
\hline 4 & & $\begin{array}{l}\beta \text {-Pinen } \\
0.4 \%\end{array}$ & 14 & & $\begin{array}{l}\alpha \text {-thujene } \\
2.2 \%\end{array}$ \\
\hline 5 & & $\begin{array}{l}\text { 1,8-Cineol } \\
0.9 \%\end{array}$ & 15 & & $\begin{array}{l}\beta \text {-myrcene } \\
1.4 \%\end{array}$ \\
\hline 6 & & $\begin{array}{l}\alpha \text {-Terpinen } \\
0.8 \%\end{array}$ & 16 & & $\begin{array}{l}\text { Carvacrol } \\
3.2 \%\end{array}$ \\
\hline
\end{tabular}


Moroccan Formulation of Oils for the Care of Hair: Chemical Composition and Antibacterial

Copyright: Activity

(C) 2016 Ainane et al.

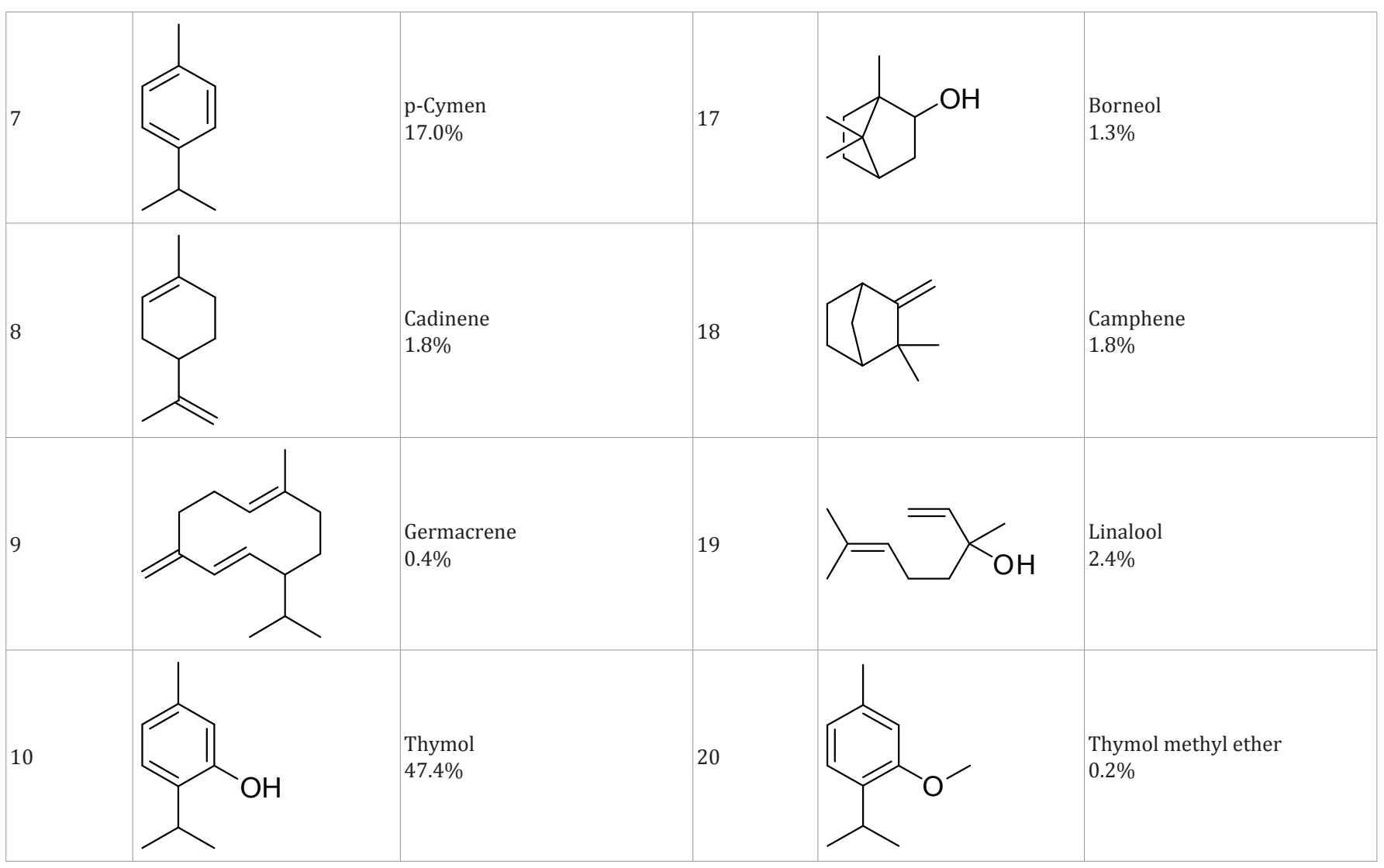

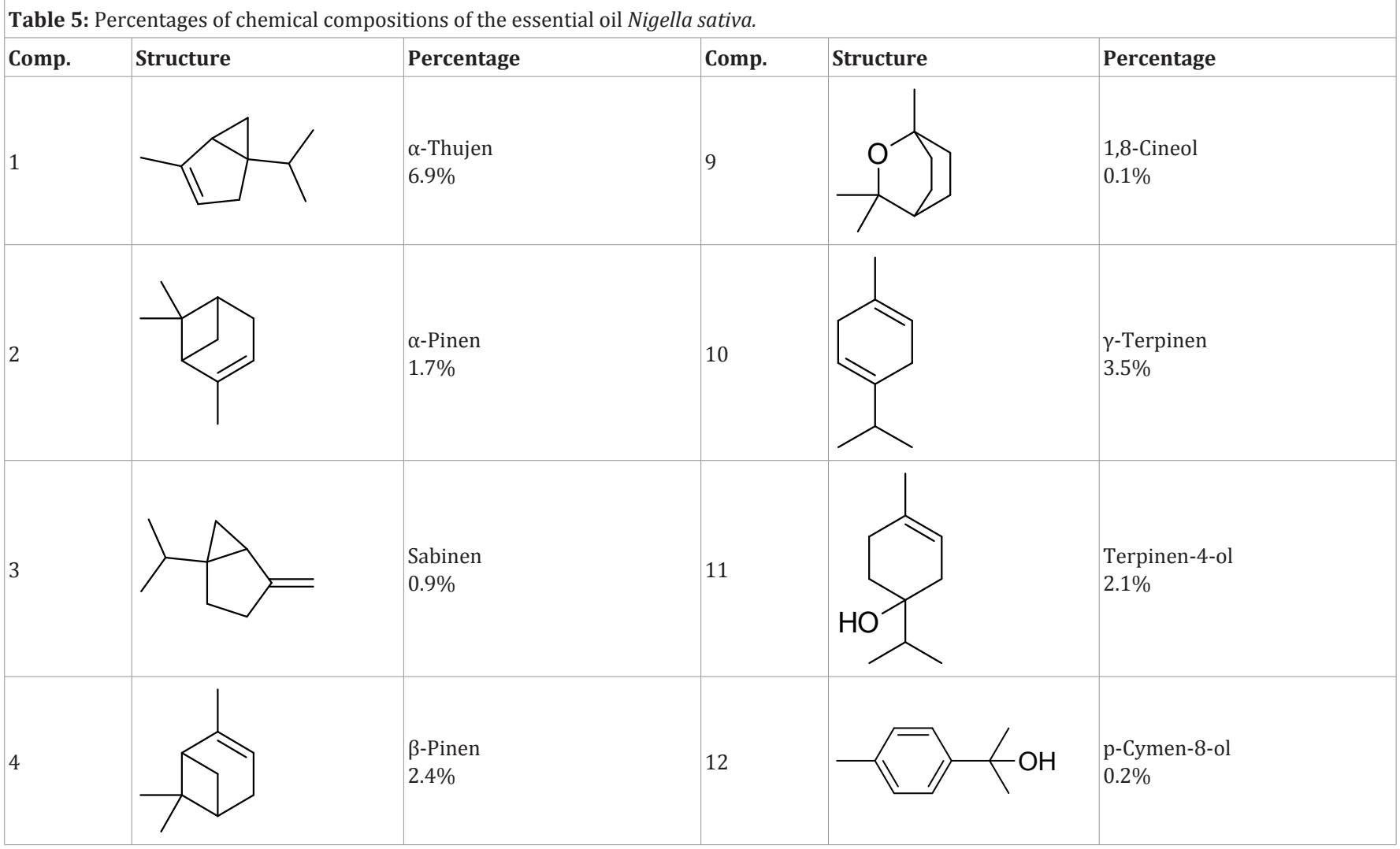

Citation: Ainane T, Gharby S, Talbi M, Abourriche A, Bennamara A, et al. (2016) Moroccan Formulation of Oils for the Care of Hair:

Page 5 of 8 


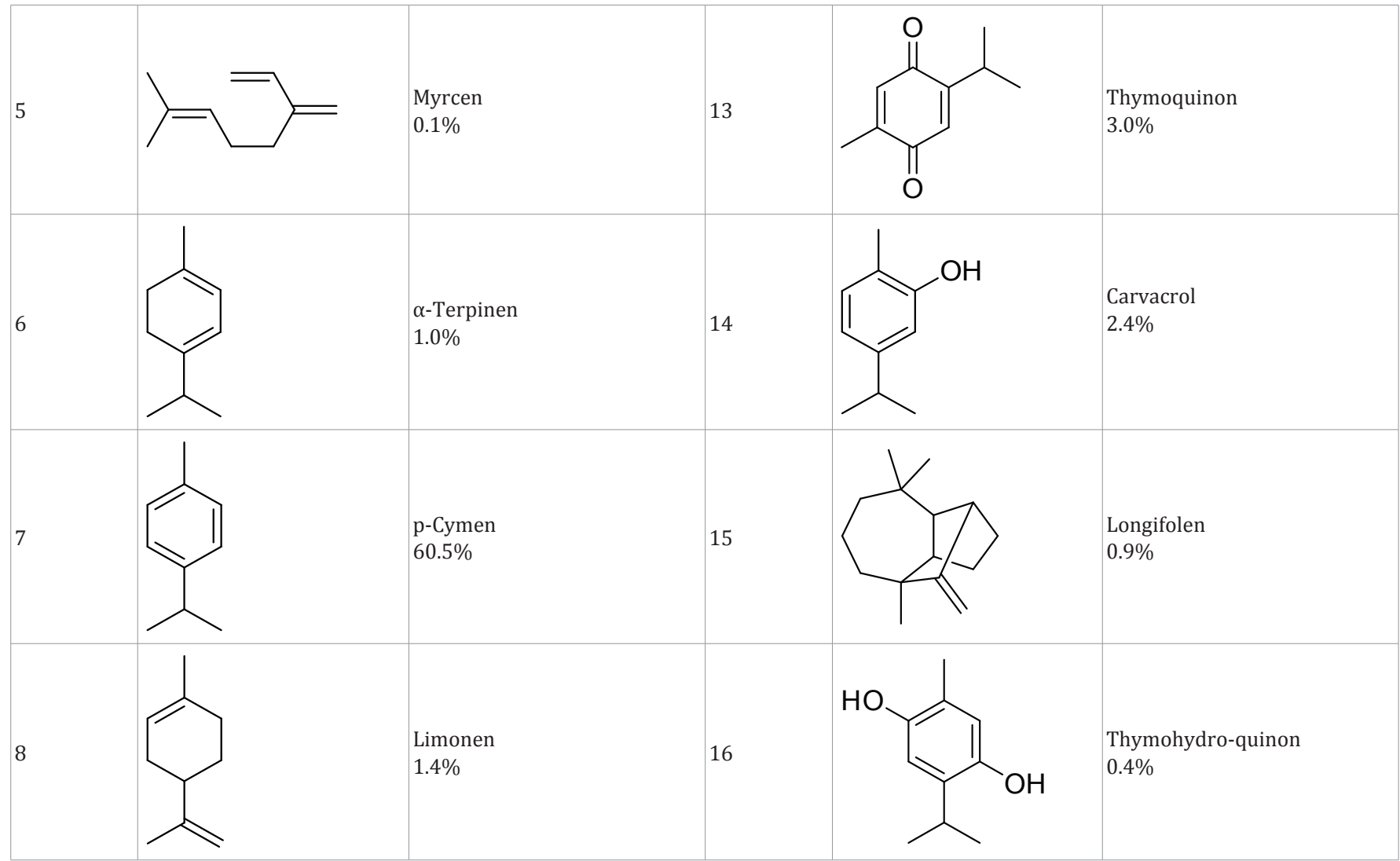

Table 6: Percentages of chemical compositions of the essential oil Allium sativum.

\begin{tabular}{|c|c|c|c|c|c|}
\hline Comp. & Structure & Percentage & Comp. & Structure & Percentage \\
\hline 1 & $\gamma$ & $\begin{array}{l}\text { Dimethyl disulfide } \\
2.3 \%\end{array}$ & 8 & & $\begin{array}{l}\text { Diallyltrisulfide } \\
15.9 \%\end{array}$ \\
\hline 2 & & $\begin{array}{l}\text { 1,2-dithiacyclo- } \\
\text { pentane } \\
0.4 \%\end{array}$ & 9 & & $\begin{array}{l}\text { Diallyltetrasulfide } \\
0.8 \%\end{array}$ \\
\hline 3 & & $\begin{array}{l}\text { Diallyl sulfide } \\
1.3 \%\end{array}$ & 10 & & $\begin{array}{l}\text { 3-Vinyl- }[4 \mathrm{H}]-1,2 \text {-dithiin } \\
7.3 \%\end{array}$ \\
\hline 4 & & $\begin{array}{l}\text { Methyl allyl disulfide } \\
4.8 \%\end{array}$ & 11 & & $\begin{array}{l}\text { 2-vinyl thiophene } \\
0.2 \%\end{array}$ \\
\hline 5 & & $\begin{array}{l}\text { Dimethyl trisulfide } \\
1.9 \%\end{array}$ & 12 & & $\begin{array}{l}\text { 3-methylthio-propanal } \\
0.2 \%\end{array}$ \\
\hline 6 & & $\begin{array}{l}\text { Diallyl disulfide } \\
18.8 \%\end{array}$ & 13 & & $\begin{array}{l}\text { Allyl 2,3-epoxypropyl-sulfide } \\
0.1 \%\end{array}$ \\
\hline 7 & & $\begin{array}{l}\text { Methyl allyltrisulfide } \\
16.3 \%\end{array}$ & 14 & & $\begin{array}{l}\text { 2-Vinyl-[4H]-1,3-dithiin } \\
3.7 \%\end{array}$ \\
\hline
\end{tabular}


Table 7: Antibacterial activity of the vegetable oils, the essential oils, the formulation, the tetracycline and streptomycin.

\begin{tabular}{|c|c|c|c|c|}
\hline Product & S. faecalis & E. coli & S. aureus & P. aeruginosa \\
\hline Argan oil & + & + & + & + \\
\hline Olive oil & - & + & + & - \\
\hline T. vulgaris & + & ++ & ++ & - \\
\hline N. sativa & + & ++ & ++ & + \\
\hline A. sativum & + & +++ & + & ++ \\
\hline Formulation & + & ++ & ++ & + \\
\hline Tetracycline & ++ & ++ & +++ & ++ \\
\hline Streptomycin & +++ & ++ & +++ & - \\
\hline
\end{tabular}

compounds were detected with an important yields such as: 3-vinyl-[4H]-1,2-dithiin (7.3\%), methyl allyl disulfide (4.8\%), 2-vinyl-[4H]-1,3-dithiin (3.7\%) and dimethyl disulfide (2.3\%).

\section{Antibacterial activities}

The vegetable oils and essential oils are the main products of the preparation of the formulation for the care of the hair. They are evaluated for antimicrobial activity against four strains Streptococcus faecalis, Escherichia coli, Staphylococcus aureus and Pseudomonas aeruginosa (Table 7) gives the results obtained during the antibacterial tests of these four strains by well diffusion agar method with a concentration of $2 \mathrm{mg} / \mathrm{ml}$ for all products.

All oils showed important activity against the four strains, except olive oil which doesn't present an activity against Streptococcus faecalis, and Pseudomonas aeruginosa, also, no activity for essential oil of Thymus vulgaris against Pseudomonas aeruginosa. Altogether, formulation prepared during this work showed remarkable activity against four strains. Finally, the positive results of this antibacterial test are achieved by the constituents of the chemical composition of all the oils and formulation, particularly fatty acids, thymol, p-cymen and sulphides; they exhibit important activities according to the literature [20,22-24].

\section{Conclusion}

This work was devoted under investigation of the chemical composition and the antibacterial activity of a formulation of the Moroccan tradition, for the care of the hair. This formulation was prepared of two vegetable oils: argan oil and olive oil, and three essential oils: Thymus vulgaris, Nigella sativa, and Allium sativum. The physicochemical analysis of vegetable oils shows that two oils had good qualities according to the international recommendations. Also, their chemical compositions give a majority composition of fatty acids and a minority composition of sterols and tocopherols. The chemical analyses of the components of essential oils shows that the three oils had interesting compounds bioactifs, from where the essential oil analysis of Thymus vulgaris gives a majority composition of thymol and p-cymen, the essential oil analysis of Nigella sativa gives a majority composition of p-cymen, and essential oil analysis of Allium sativum gives a majority composition of diallyl disulfide, methyl allyl trisulfide and diallyl trisulfide.

Finally, the antibacterial test of the formulation gives an important activity against Streptococcus faecalis, Escherichia coli, Staphylococcus aureus and Pseudomonas aeruginosa. The appearance of this activity is caused by bioactive compounds present in components of vegetable oils and essential oils.

\section{References}

1. Khan IA, Abourashed EA. Leung's encyclopedia of common natural ingredients: used in food, drugs and cosmetics. John Wiley \& Sons; 2011.

2. Achilladelis B, Antonakis N. The dynamics of technological innovation: the case of the pharmaceutical industry. Research Policy. 2001;30(4):535-588. DOI:10.1016/S0048-7333(00)00093-7.

3. Eshun K, He Q. Aloe Vera: a valuable ingredient for the food, pharmaceutical and cosmetic industries-a review. Crit Rev Food Sci Nutr. 2004;44(2):91-6. DOI: 10.1080/10408690490424694.

4. Lubbe A, Verpoorte R. Cultivation of medicinal and aromatic plants for specialty industrial materials. Industrial Crops and Products. 2011;34(1):785-801. DOI:10.1016/j.indcrop.2011.01.019.

5. Ainane T, Elkouali M, Ainane A, Talbi, M. Moroccan traditional fragrance based essential oils: Preparation, composition and chemical identification. 2014;6(6):84-89.

6. Burssens S, Ingelbrecht I, Van Montagu M, De Oliveira D, Pertry I. Green biotechnology applications for industrial development: opportunities and challenges for cooperation between the EU and the Mercosur. Mercosur European Union dialogue. 2013;80-97.

7. Bekatorou A, Plessas S, Mantzourani I. Biotechnological Exploitation of Brewery Solid Wastes for Recovery or Production of Value-Added Products. Advances in Food Biotechnology: John Wiley \& Sons; 2015.

8. Daughton CG, Ternes TA. Pharmaceuticals and personal care products in the environment: agents of subtle change? Environ Health Perspect. 1999;107;6:907-38. DOI: 10.1016/j.watres.2009.12.032.

9. Kumar S. Exploratory analysis of global cosmetic industry: major players, technology and market trends. Technovation. 2005;25(11):1263-1272. DOI:10.1016/j.technovation.2004.07.003.

10. Faysse N, Errahj M, Imache A, Kemmoun H, Labbaci T. Paving the way for social learning when governance is weak: Supporting 
dialogue between stakeholders to face a groundwater crisis in Morocco. Society \& Natural Resources. 2014;27(3):249-264. DOI: 10.1080/08941920.2013.847998.

11. Jarlan L, Driouech F, Tourre Y, Duchemin B, Bouyssié M, Abaoui J, et al. Spatio-temporal variability of vegetation cover over Morocco (1982-2008): linkages with large scale climate and predictability. International Journal of Climatology. 2014:34(4):1245-1261. DOI:10.1002/joc.3762.

12. Nasir, M. Taxonomic perspective of plant species yielding vegetable oils used in cosmetics and skin care products. African journal of biotechnology. 2005;4(1):36-44.

13. Ryan E, Galvin K, O'Connor TP, Maguire AR, O'Brien NM. squalene, tocopherol content and fatty acid profile of selected seeds, grains, and legumes. Plant Foods Hum Nutr. 2007;62(3):85-91. DOI: 10.1007/ s11130-007-0046-8.

14. Charrouf Z, Guillaume D. Argan oil: Occurrence, composition and impact on human health. European Journal of Lipid Science and Technology. 2008;110(7):632-636. DOI: 10.1002/ejlt.200700220.

15. Bassolé IH, Juliani HR. Essential oils in combination and their antimicrobial properties. Molecules. 2012;17(4):3989-4006. Doi: 10.3390/molecules17043989.

16. Salem M.Z, Zidan YE, Mansour MM, El Hadidi NM, Elgat WAA Antifungal activities of two essential oils used in the treatment of three commercial woods deteriorated by five common mold fungi. International Biodeterioration \& Biodegradation. 2016;106:88-96. DOI:10.1016/j.ibiod.2015.10.010.

17. Commission Regulation (EEC) 2568/91 on the characteristics of olive oil and olive-residue oil and on the relevant methods of analysis. Official Journal of the European Communities. 1991;248:1-82.
18. Gharby S, Harhar H, Guillaume D, Haddad A, Matthäus B, Charrouf Z, et al. Oxidative stability of edible argan oil: A two-year study. LWT-Food Science and Technology. 2011;44(1):1-8. DOI:10.1016/j. lwt.2010.07.003.

19. American oil chemist's society. Determination of tocopherols and tocotrienols in vegetable oils and fats by HPLC. Uniform Methods Committee. AOCS Official Method Ce 8e89. 1993; Champaign, II: AOCS.

20. Ainane T, Askaoui Z, Elkouali M, Talbi M, Lahsasni S, Warad I, et al. Chemical composition and antibacterial activity of essential oil of Nigella sativa seeds from Beni Mellal (Morocco): What is the most important part, Essential Oil or the rest of seeds?. Journal of Materials and Environmental Science. 2014;5(6):2017-2020.

21. Ainane T, Abourriche A. Brown Seaweed Bifurcaria bifurcata: Bioguided Fractionation of Extracts by Antibacterial Activity and Cytotoxicity Test. Biosciences Biotechnology Research Asia. 2014;11(3):1081-1085. DOI: 10.13005/bbra/1492.

22. Zheng CJ, Yoo JS, Lee TG, Cho HY, Kim YH, Kim WG, et al. Fatty acid synthesis is a target for antibacterial activity of unsaturated fatty acids. FEBS Lett. 2005;579(23):5157-62. doi:10.1016/j. febslet.2005.08.028.

23. Gavaric N, Mozina SS, Kladar N, Bozin B. Chemical Profile, Antioxidant and Antibacterial Activity of Thyme and Oregano Essential Oils, Thymol and Carvacrol and Their Possible Synergism. Journal of Essential Oil Bearing Plants. 2015;18(4):1013-1021. DOI: 10.1080/0972060X.2014.971069.

24. Casella S, Leonardi M, Melai B, Fratini F, Pistelli L. The role of diallyl sulfides and dipropyl sulfides in the in vitro antimicrobial activity of the essential oil of garlic, Allium sativum L, and leek, Allium porrum L. Phytother Res. 2013;27(3):380-3. Doi: 10.1002/ptr.4725. 